\title{
The Movie as a Helper for Students' Pronunciation in Speaking Skill Class
}

\author{
Ratih Saltri Yudar ${ }^{1}$, Dionisius Tito Aditomo ${ }^{2}$, and Novia Sariahta Silalahi ${ }^{3}$ \\ ${ }^{1}$ U-RAISE Academy, Pekanbaru, Indonesia \\ ${ }^{2,3}$ Universitas Lancang Kuning, Pekanbaru, Indonesia \\ ratihsaltri34@gmail.com
}

\begin{abstract}
ARTICLE HISTORY
Received : 23 February 2020

Revised : 26 February 2020

Accepted : 26 February 2020
\end{abstract}

\section{KEYWORDS}

\author{
Movie \\ Speaking Skill \\ Learning Media \\ English Skill \\ English as a Foreign Language \\ (EFL)
}

\begin{abstract}
This research aims to deliver how a movie can help students with their pronunciation in English speaking skill. Speaking is one of English skill that has an important role. While speaking, there is a certain aspect that has to be paid attention by people. Pronunciation is an aspect that important in speaking skill. Pronunciation takes a significant role in speaking because it shows anything while someone speaks and other people understanding based on how someone pronounces a word. This study is aimed for students who learn the English language as a foreign language (EFL) to drive the importance this area. With qualitative method, this study hopes to avoid people from misunderstanding what nonEnglish native speakers say. This study's discussion drives the urgency to teach speaking with the learning activities designed as well as possible to address pronunciation. This study also recommends parties in educational sector to support the use of various teaching media such as videos pictures, realia, television, but particularly movies. This is because a movie is one of the media that can immensely help student's speaking ability as they actively engage and have fun in imitating the audiovisual feed they receive.
\end{abstract}

\section{Introduction}

Currently, the world demands higher educations to integrate learning with technology. The benefits are countless, and more or less worth the consequences of being severely left behind in the day-to-day lives of developed countries. Even in developing countries, despite the constant complaints regarding educational institutions' lack of facility to support the use of information and communication technology (ICT), the huge majority of people calls for the maximum use of online learning media. The principles of twentieth-century education are collaboration, critical thinking, creative thinking, and computer literacy (Menggo, Suastra, Budiarsa, \& Padmadewi, 2019). Conveniently, these pedagogical principles align with multimedia principles of cooperation, collaboration, and communication (Anderson, 2008).

Of course, while the progress of online learning media permeating educational sectors is highly rapid, it guarantees to encounter several problems in practice. Hamuddin, Syahdan, Rahman, Rianita, \& Derin (2019) presented significant evidence of students' prevalent motives for engaging in online activities that actually go against positive interpersonal communication. However, holistic education must continue to practice, test, and improve old and new ways of learning, and one of the most dug areas of research is in the context of improving students' speaking skill. Learning media can improve any aspect of education and any learning goal, limited only by people's innovative minds, but this study focuses especially on speaking improvement because spoken communication's extremely crucial role in almost every real-life aspects of students' lives.

At a glance in these current times, there are obvious media that can and has been used to enhance the learning and teaching process of speaking skills. Visual media, such as pictures has a lengthy history of being advocated by researchers and teaching practitioners to improve students' speaking skills (Baidawi, 2016; Gistituati, Refnaldi, \& Syaifullah, 2018). Using audiovisual materials from open access video databases such as YouTube to learn not just important values but also improve speaking skills is one of the easiest ways to blend formal classrooms to outside-class learning situations (Anwar, Derin, Nursafira, Putri, \& Jazzawi, 2020; Susilo, 2019). Pushing students toward the top-most tier of Bloom's taxonomy by encouraging them to actively create vlogs has also become a popular pedagogical tactic (Lestari, 2019; Safitri \& Khoiriyah, 2017). Others suggested less popular but nevertheless useful interactive software such as Rosetta Stone (Yurdean \& Syafei, 2016).

Four skills, listening, speaking, reading and writing are available in English. Ideally, the teacher must integrate all four skills so that students have good English skills, whether in written language or in spoken language. And for additional learners, speaking is the most important one because they want to use English as a tool to communicate more globally. Mastering speech is the only significant aspects of second-language learning, and the progress is 
assessed by the ability to conduct a conversation in the language. In particular, greater attention should be paid to pronunciation so that students can actively speak English and pronounce words correctly.

Some learning media, however, stands out to this current study as they tackled speaking skill enhancement in a much more specific way, namely by improving students' pronunciations. Duolingo, one of the most used foreign language learning applications in the world, provides learners with audio of every single text in each question in the online classes, letting students freely imitate the sounds (Mahmudah, 2015). The social media Twitter and Telegram have been proven to be effective in improving students' pronunciations (Mompean \& Fouz-González, 2016; Xodabande, 2017).

Teaching speaking therefore not only teaches students to produce spoken words in order to express their feelings, ideas and minds but also to enable students in negotiating to mean use common knowledge of the situation and the subject. Speaking refers to being capable of effectively speaking in a specific context in order to communicate information, to express ideas and feelings and to build a social relationship in the form of varied, normal, engaging and exciting activities.

Many students should always memorise new vocabulary, speak words, use the grammar appropriately and correctly, communicate their ideas clearly, and reduce anxiety. And some students could not think of anything abstract if they wish to speak, but they can't pronounce words correctly so that the student doesn't participate in speech classes actively

There are still some things the English teacher can do to fix the students ' pronunciation issues in the classroom, however. One is to use a film that is ideal for the methods and techniques to be used in the classroom. Learning material should be designed to accommodate every learner, style of learning, and not just teaching styles. One effective way to achieve this is through the use of a wide range of media, particularly films, which are currently suitable for learners.

The movie is a visual art used to simulate experiences that communicate ideas, stories, perceptions, feelings, beauty or atmosphere using recorded or programmed moving images along with other sensory stimulations. The movie is created by photographing actual scenes with a motion-picture camera, by photographing drawings or miniature models using traditional animation techniques, using CGI and computer animation, or by a combination of some or all these techniques and other visual effects that can gain students interest. The movie now a day has lots of types that will match what students like or interest. Movie is now widely available in cinema, a platform like YouTube, or the videotaped movie that available for purchase, making them an accessible resource for students to fix their pronunciation because movie actors and actress can offer a way of how a words pronounce correctly, and students can adopt how the actors or actress of western movie pronouncing the words. This research purposed to describe how a movie can help students speaking skill, especially in pronunciation.

\section{Method}

This research employs qualitative research as its methodology. The qualitative method is concerned with meaning as they appear to or are achieved by a person in a lived social situation (Umanailo, Hamid, Hamiru, Assagaf, Bula, Nawawi, Pulhehe, Yusuf, \& Bon, 2019). Qualitative research is descriptive, which the data collected in the form of words or pictures rather than numbers.

The source of the data in this research subjects from which data can be obtained. The data quoted from documents, articles, and field notes. This research used a scheme of a descriptive method, which is a method of research that attempts to describe and interpret how a movie can be a helper for students' pronunciation ability in speaking skill.

This research construct with a descriptive analysis of how a movie can help students' with their pronunciation and add a more comprehensive explanation. In the analysis process, it takes some steps to collect data, such as categorising, interference, validating data, and conclude. The categorising is grouping data based on predetermined categories according to the purposes of the research, followed by validating data of the analysis that carried out by read some article repetitively, make a conclusion based on the results of the analysis, and the last step is interference the data.

\section{Results}

Speaking is one of the productive skills that must be mastered by students while learning a language. Students have to be able to give their opinion, express their feeling in speaking without hesitation or fear. Speaking skills are used for many different purposes, each purpose involves different skills, such as establish rapport or to engage in the friends, to seek or express an opinion, to persuade someone about something or clarify information". It is shown that students cannot get stuck while speaking just because they cannot pronounce some words well, and it can cause a misunderstanding. Because speaking skill is a performance skill that students cannot just see what the teachers perform.

Moreover, pronunciation is an important yet often neglected subfield in Second Language Acquisition, both in pedagogy and research. Pronunciation leads students to understand better native speakers and native-like speakers properly and improves their ability to communicate with other people, especially native using English. Learning about pronunciation develops the students' abilities to comprehend spoken language. When pronounce is learned properly, the speaker can be understood by the hearer even if she makes mistakes in other areas of language. Students 
who learn English as a foreign language may have problems with communication their pronunciation is not at an expected level. Therefore, the students need to practice how to pronounce words by themselves, so they can understand how to pronounce something correctly. Moreover, teachers can give the right samples to pronounce words and correct them when they make mispronounce while they speak.

The difficulty of learning to pronounce words from a foreign language is cognitive rather than physical. And something that has to do with the raw sound is categorised or conceptualised in using speech, especially in daily life. Many learners of English as a foreign language have major difficulties with the pronunciation of the words even after a few years of learning the English language. Based on a certain proficiency standard, the fault which most severely impairs the communication process in English foreign language or English second language learners is pronunciation, not vocabulary or grammar. Students may pronounce some words incorrectly that change the meaning of those words, because, in English, some words may have the same sounds but different meanings. The research entitled "A Brief Comparison of the Current Approaches in Teaching Pronunciation" said that the sounds different between the mother tongue and the target language are one of the sources of pronunciation problems.

The importance of speaking in the language classroom is not just as a communication skill, but also a means of facilitating the acquisition of the target language and the learning of academic content. Ideally, in the activities of the teaching-learning process, the teacher should provide a chance to give input and feedback for the students and also encourage each student to drill to produce well-formed utterances. One way to solve this problem is the teacher should develop some exciting activities in a group work that can attract students' attention to linguistic forms in their speech and can further develop students' ability to speak accurately.

These days, students more likely to learning with media because it can help them to understand some materials that they cannot understand just by listening to what was explain by the teachers. Learning style defines how learners interact, acquire knowledge, or respond to stimuli in their learning environments. An understanding of awareness into various learning styles can help both teachers and students. Teachers can design and customize teaching activities that use media to address the different situation of learning styles more effectively in order to support students learning activities. And teachers should give effective instruction in the speaking class, but the importance of giving effective instructions should not be underestimated in the classroom while teachers teach about pronunciation.
According to Kemp \& Dayton (1985), there are some significant contributions of using media in the learning process such as delivery of learning messages can be more standardised, learning can be more exciting and interactive, the quality of learning could be improved, the learning process also can take place whenever and wherever needed, and the last, the positive attitudes of students to learning materials and learning process can be improved. Movie with its own unique and exciting side can be an exciting learning media for students to fix their pronunciation through how words pronounced by the actors and actress and movie gain students interest as well.

Since the 1970s, teachers have experienced in using a movie as a teaching tool have urged its adoption by others. Movie literature studies have suggested some unique features of a movie can make it an uncommonly powerful teaching tool and make students enjoy to learn speaking skill. Movie theorist Siegfried Kracauer on 1973 captured this view of a movie when he said that a unique property of movie is its ability to "make one see and grasp things which only the cinema is privileged to communicate," (Hansen \& Hansen, 2012).

The movie has its unique aspects, and movie making let this media portray organisational behaviour and management concept in an uncommonly powerful way that makes students gain more interest in studying speaking skill, especially pronounce words correctly. At the same time, they talk or have a conversation using English. Understand the example of how actors and actress pronounce words while they were in a conversation or talk about something scenes and teachers with students can discuss it later when the movie ends. It also helps guide the selection of another movie to show concepts of interest teachers in English class.

Interpersonal actors in a movie that is an interpersonal dialogue are more committed to the maintenance of a social relationship than to the transmission of facts and information. These conversations are a little tricky for students as some or all of these factors may be involved, such as casual recordings, colloquial language, emotions, slang, ellipsis and sarcasm. Learners should know how many features interlocutor partnerships have.

The unique characteristics of a movie are making additions to its communication power. Focusing techniques, editing, the framing of shots, camera angles, sound, conversation scenes, and the like help a director make a powerful statement of a subject. These techniques also let a director create an experience of learning that often goes beyond what students can experience in reality. Students may not be able to comment about the movie, but from a movie, they can adopt the way each word pronounced by the actors or actress.

Speaking is a class that is not expected to be monotonous. So that the students with different learning styles and strategies can have the same chance to participate in learning activities, in the classroom, the teacher must 
design many kinds of classroom speaking performance to be done by students. Learners, in particular beginners, need templates or examples to mimic the way words are pronounced or sentences articulated with proper stress and intonation. This type of imitation is done not for meaningful interaction, but to concentrate on certain particular elements of the language form. And the movie can help students with their pronunciation with imitating the way the actors or actress pronounce each word while their talk or in a conversation scene. In his work titled, "The use of visual aids in improving students ' speaking skills," Syaifullah et al. (2018) said, "Visual assistance can help students communicate." It means media with imagery such as visual aids, videos, etc. can help students to enhance their speaking skills and fix some problems of the students speaking skills.

A movie can be a media that support teachers while teaching pronunciation in speaking skills, especially American movie, because the actors or the actress is native speakers and students can imitate the way they pronounce words. Furthermore, teachers still have a responsibility to give an example of how to pronounce words when teaching in the classroom and correct the students when they were trying to speak or communicate in English.

When teachers use a movie as learning media to fix students pronunciation for speaking skill, teachers should choose a movie that suits the students well and show how each word pronounce well by the artist. Teachers should become aware of some side of a movie that is not good for students' learning that can be unexpected problems in the learning process, so teachers should choose a movie that suite a learning process.

\section{Conclusion}

Pronunciation is part of speaking skill that cannot be left out because it is an important part. Pronunciation has its own problems for EFL students because it is not the students' mother tongue language. Students may not pronounce English words properly, or they might pronounce it in the wrong way and caused a misunderstanding from someone who hears that. Therefore, teachers should find the right way or strategy and especially a media to teach pronunciation in the speaking class. Media become an important part that can help the teacher in the class and to get students to interest in speaking class. Teachers can use media that centre on student life these days, such as movie, social media, or other things that students prefer.

\section{Acknowledgement}

The researchers thank their colleagues from UnilakResearch Advancement for Intellectual and Scientific Empowerment (U-RAISE) Academy, Applied Linguistics Center, as well as LPPM Unilak for their support and advice during the discussions.

\section{References}

Anderson, T. (Ed.). (2008). The theory and practice of online learning. Athabasca University Press.

Anwar, A., Derin, T., Nursafira, M. S., Putri, N. S., \& Jazzawi, I. (2020). Delivering Positive Message Through\# BaliAman Vlog: President Joko Widodo's Communication Strategy. Journal of Election and Leadership, 1(1), 57-63.

Baidawi, A. (2016). Using Visual Media in Teaching Speaking. OKARA: Jurnal Bahasa dan Sastra, 10(1), 54-65.

Gistituati, N., Refnaldi, R., \& Syaifullah, S. (2019, January). Using Visual Aids to Develop Students' Speaking Skill. In International Conference on Islamic Education (ICoIE 2018). Atlantis Press.

Hamuddin, B., Syahdan, S., Rahman, F., Rianita, D., \& Derin, T. (2019). Do They Truly Intend to Harm Their Friends?: The Motives Beyond Cyberbullying among University Students. International Journal of Cyber Behavior, Psychology and Learning (IJCBPL), 9(4), 32-44.

Hansen, M. B., \& Hansen, M. B. (2012). Cinema and Experience: Siegfried Kracauer, Walter Benjamin, and Theodor W. Adorno (Vol. 44). Univ of California Press.

Kemp, J. E., \& Dayton, D. K. (1985). Planning and producing instructional media. Harper \& Row.

Lestari, N. (2019). Improving the Speaking Skill by Vlog (video blog) as Learning Media: The EFL Students Perspective. International Journal of Academic Research in Business and Social Sciences, 9(1), 915925.

Mahmudah, L. (2015). An analysis of pronunciation exercises in Duolingo application and its contribution as English learning media (Doctoral dissertation, UIN Walisongo).

Menggo, S., Suastra, I., Budiarsa, M., \& Padmadewi, N. N. (2019). Needs Analysis of Academic-English Speaking Material in Promoting 21st Century Skills. International Journal of Instruction, 12(2), 739-754.

Mompean, J. A., \& Fouz-González, J. (2016). Twitterbased EFL pronunciation instruction. Language Learning \& Technology, 20(1), 166-190.

Nunan, D. (1999). Second Language Teaching \& Learning. Heinle \& Heinle Publishers, 7625 Empire Dr., Florence, KY 41042-2978.

Safitri, N. S. A., \& Khoiriyah, I. (2017, July). Students' Perceptions on the Use of English Vlog (Video Blog) to Enhance Speaking Skill. In ASEAN/Asian 
Academic Society International Conference Proceeding Series.

Susilo, N. (2019). Kahoot Apps in ELT Context: An alternative Learning Strategy. ELSYA: Journal of English Language Studies, 1(1), 11-15.

Umanailo, M. C. B., Hamid, I., Hamiru, H., Assagaf, S. S. F., Bula, M., Nawawi, M., Pulhehe, S., Yusuf, S. \& Bon, A. T. (2019). Utilization of Qualitative Methods in Research Universities. Education science, 21(36), 20.

Xodabande, I. (2017). The effectiveness of social media network telegram in teaching English language pronunciation to Iranian EFL learners. Cogent education, 4(1), 1347081.

Yurdean, P., \& Syafei, A. F. R. (2016). Using Rosetta Stone as Learning Media to Increase Speaking Skill for Junior High School Students. Journal of English Language Teaching, 5(1), 357-361. 